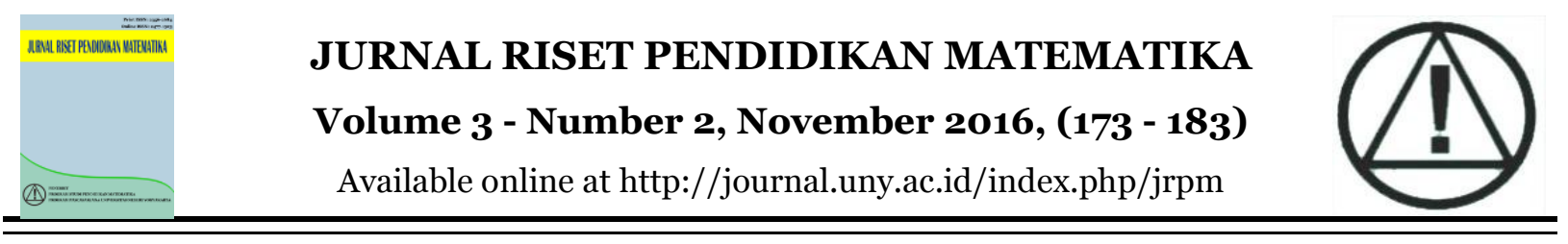

\title{
PENGEMBANGAN PERANGKAT PEMBELAJARAN STATISTIKA SMP DENGAN PENDEKATAN SAINTIFIK
}

\author{
Choirul Mahmudah \\ SMP Negeri 1 Tulang Bawang Udik, Jalan Kartini No 12, Tulang Bawang, Lampung 34691, Indonesia \\ Korespondensi Penulis. Email: choirulmahmudah1986@gmail.com, Telp: +6285769825334 \\ Received: $2^{\text {nd }}$ February 2016; Revised: $3^{\text {rd }}$ October 2016; Accepted: $18^{\text {th }}$ October 2016
}

\begin{abstract}
Abstrak
Penelitian ini bertujuan untuk menghasilkan perangkat pembelajaran statistika SMP dengan pendekatan saintifik, meliputi rencana pelaksanaan pembelajaran (RPP) dan lembar kegiatan siswa (LKS) yang valid, praktis dan efektif. Penelitian ini adalah penelitian pengembangan mengacu model pengembangan Borg \& Gall. Sebagai sumber data, dilibatkan enam orang siswa kelas IX, 56 siswa kelas VII, dan tiga orang guru SMP Negeri 1 Tulang Bawang Udik, Provinsi Lampung. Data diperoleh dengan menggunakan instrumen lembar validasi, lembar observasi keterlaksanaan pembelajaran, lembar penilaian kepraktisan oleh siswa, lembar keterbacaan, lembar penilaian kepraktisan oleh guru, dan instrumen kefektifan perangkat pembelajaran. Analisis data dilakukan dengan mengkonversi total skor data kuantitatif yang diperoleh menjadi data kualitatif skala lima. Hasil validasi ahli menunjukkan bahwa RPP dan LKS sangat valid. Hasil Penilaian guru menunjukkan bahwa produk mencapai kriteria sangat praktis dan hasil penilaian siswa menunjukkan bahwa RPP dan LKS sangat praktis. Hasil pengisian angket keterbacaan siswa menunjukkan LKS sangat jelas dan keterlaksanaan pembelajaran 96\%. Hasil penilaian hasil belajar aspek sikap, pengetahuan, dan keterampilan menunjukkan persentase ketuntasan melebihi $75 \%$. Hal ini menunjukkan bahwa RPP dan LKS memenuhi kriteria efektif. Secara keseluruhan hasil penelitian menunjukkan bahwa RPP dan LKS statistika SMP dengan pendekatan saintifik memenuhi kriteria: valid, praktis, dan efektif.
\end{abstract}

Kata Kunci: pengembangan, perangkat pembelajaran, statistika, pendekatan saintifik

\section{DEVELOPING STATISTICS TEACHING KITS FOR JUNIOR HIGH SCHOOL USING THE SCIENTIFIC APPROACH}

\begin{abstract}
This study aimed to produce statistics teaching kits for junior high school using the scientific approach, consisting of lesson plans and students's worksheets which are valid, practical, and effective. This was a research and development study. The development procedure employed the model developed by Borg \& Gall. As data resources, six students of Grade IX, 27 students of Grade VIIA, 29 students of Grade VIID, and three teachers of SMPN 1 Tulang Bawang Udik, Lampung Province were involved. The research instruments were validation sheets, observation sheets for the learning implementation, assessment sheets for the practicality according to the students, readability sheets, assessment sheets for the practicality according to the teachers, and the instruments for the effectiveness of the learning kits. The data were analyzed by converting the total scores of the collected quantitative data into the qualitative data using Likert's scale. The results of the validation by the experts show that the product was very valid. The results of assessment by the teachers show that lesson plans and students's worksheets were very practical and the results of assessment by the students show that students's worksheets was very practical. The results of the readability questionnaire for the students show that the product was very clear. The results of learning implementation show that $96 \%$ accomplished. The percentage of students' mastery learning on affective, cognitive, and psychomotor aspects were more than $75 \%$. This shows that the teaching kits were effective. On the whole, the results of the study show that the teaching kits were valid, practical, and effective.
\end{abstract}

Keywords: development, teaching kits, statistics, scientific approach

How to Cite: Mahmudah, C. (2016). Pengembangan perangkat pembelajaran statistika SMP dengan pendekatan saintifik. Jurnal Riset Pendidikan Matematika, 3(2), 173-183. doi:http://dx.doi.org/10.21831/jrpm.v3i2.9806 


\section{PENDAHULUAN}

Pemerintah memiliki peranan penting dalam perkembangan pendidikan. Undang-Undang 20 Tahun 2003 tentang Sistem Pendidikan Nasional meyebutkan pendidikan adalah usaha sadar dan terencana untuk mewujudkan suasana belajar dan proses pembelajaran agar siswa secara aktif mengembangkan potensi dirinya untuk memiliki kekuatan spiritual keagamaan, pengendalian diri, kepribadian, kecerdasan, akhlak mulia, serta keterampilan yang diperlukan dirinya, masyarakat, bangsa dan negara.

Menghadapi perkembangan ilmu pengetahuan dan teknologi serta arus globalisasi, pemerintah terus menerus melakukan perbaikan di sektor pendidikan. Terbaru, pemerintah mengeluarkan kebijakan memperbaiki Kurukulum 2006 menjadi Kurikulum 2013. Kurikulum 2013 dikembangkan dengan penyempurnaan pola pikir antara lain: pembelajaran berpusat kepada siswa, pembelajaran interaktif, pola pembelajaran aktif, pola pembelajaran kelompok dan pola pembelajaran kritis.

Kurikulum 2013 memuat tiga standar yaitu: standar proses, standar isi, dan standar penilaian. Standar proses memuat aturan bagaimana kegiatan pembelajaran berlangsug. Standar isi memuat kompetensi dan materi yang diberikan untuk setiap jenjang pendidikan. Sedangkan standar penilaian memuat aturan penilaian untuk setiap jenjang pendidikan.

Peraturan Menteri Pendidikan dan Kebudayaan Nomor 64 Tahun 2013 menjelaskan tentang standar isi pendidikan dasar dan menengah. Peraturan ini secara rinci menjelaskan ruang lingkup materi dan tingkat kompetensi yang harus dipenuhi atau dicapai satuan pendidikan dalam jenjang dan jenis pendidikan di Indonesia. Salah satu materi wajib yang diajarkan pada jenjang Sekolah Menengah Pertama (SMP) adalah matematika.

Materi matematika diberikan untuk membekali peserta didik kemampuan berpikir logis, analitis, sistematis dan kreatif untuk menyelesaikan masalah di berbagai bidang. DfEE (Haylock \& Thangata, 2007. p.3) menyatakan bahwa matematika memiliki peranan penting dalam kehidupan sehari-hari, pada berbagai jenis pekerjaan, sains dan teknologi, kedokteran, ekonomi, lingkungan dan pembangunan bahkan dalam pengambilan keputusan. Permendikbud Nomor 58 Tahun 2014 menjelaskan bahwa matematika merupakan sarana komunikasi yang kuat, singkat dan jelas, dapat digunakan untuk menyajikan informasi, meningkatkan kemampuan berpikir logis, ketelitian, dan kemampuan memecahkan masalah yang menantang.

Kemampuan matematika siswa SMP di Indonesia masih rendah. Fakta ini diperoleh dari hasi Nilai Ujian Nasional tahun 2014/2015 yang menunjukkan rata-rata nilai matematika SMP nasional adalah 56,40. Capaian tersebut paling rendah jika dibandingkan dengan mata pelajaran lainnya yang diujikan dalam Ujian Nasional, sebagaimana dapat dilihat pada Tabel 1 .

Tabel 1. Hasil Ujian Nasional Tahun 2014/2015 Jenjang SMP

\begin{tabular}{lcc}
\hline \multicolumn{1}{c}{ Nilai Ujian } & Rata-rata & Kategori \\
\hline Bahasa Indonesia & 71,66 & $\mathrm{~B}$ \\
Bahasa Inggris & 60,51 & $\mathrm{C}$ \\
Matematika & 56,40 & $\mathrm{C}$ \\
IPA & 60,16 & $\mathrm{C}$ \\
\hline
\end{tabular}

National Council of Teachers of Mathematics (2000, p.20) menyatakan bahwa mempelajari matematika dengan pemahaman, membangun pengetahuan baru dari pengalaman, dan pengetahuan sebelumnya akan memudahkan pembelajaran matematika selanjutnya. Senada dengan hal tersebut Kenedy, Tipss, \& Johnson (2008, p.55) menyatakan bahwa pembelajaran matematika akan bermakna apabila berorientasi pada siswa. Ditambahkan dalam NCTM (2000, p.221) bahwa pembelajaran matematika di kelas menengah, siswa harus terlibat aktif terkait dengan kemampuan menemukan dan menentukan struktur, menduga dan memverifikasi, berpikir tentang hipotesis, memahami sebab akibat, abstraksi dan menarik kesimpulan.

Pemendikbud Nomor 103 Tahun 2014 tentang Standar Proses kegiatan pembelajaran menyebutkan bahwa pada setiap jenjang pendidikan menggunakan pendekatan saintifik. Menurut Direktorat Pembinaan SMP (2014, p.203) pendekatan saintifik adalah pendekatan pembelajaran yang menerapkan tahapan metode ilmiah atau scientific method.

Metode ilmiah atau scientific method merupakan langkah atau tahap teratur dan sistematis yang digunakan dalam memecahkan masalah ilmiah. Carey (2011, p.3) menyatakan seorang ilmuwan akan mematuhi prinsip-prinsip dari scientific method dimulai dengan mengobservasi, mengajukan spekulasi, dan mencari jalan untuk menguji spekulasi tersebut. Setiap langkah yaitu: observasi, penjelasan dan menguji adalah gambaran yang bagus dari peristiwa yang pernah dideskripsikan. 
Al-Atabi \& Namasivayam (2013, p.1) menjelaskan langkah scientific method meliputi observasi, merumuskan pertanyaan, membuat prediksi logis, melakukan eksperimen dan menarik kesimpulan. Senada dengan pendapat tersebut Rothchild (2006, p.4) menyatakan scientific method yang benar adalah menggunakan apapun sehingga kita dapat mengobservasi, bertanya dan menjawab pertanyaan, menyelesaikan masalah dan menguji teori. Glazunov (2012, p.9) menyatakan scientific method konsisten dengan mengumpulkan data melalui observasi dan eksprimen, merumuskan dan mencoba hipotesis. Gould (2001, p.52) menyatakan scientific method memiliki tujuh tahap utama, yaitu: (1) merumuskan masalah, (2) merumuskan hipotesis, (3) mendesain studi, (4) mengumpulkan dan merorganisasi data, (5) merangkum dan mengolah data secara statistik, 6) mengevaluasi hasil dan menarik kesimpulan hipotesis, (7) mengomunikasikan apa yang ditemukan.

Metode saintifik pertama kali diperkenalkan ke ilmu pendidikan di Amerika pada akhir abad ke-19 (Rudolph, 2005, p.344). Kneidel (1998, p.2) menyatakan langkah scientific method yang diaplikasikan untuk pembelajaran siswa adalah: observasi, pertanyaan, hipotesis, metode, hasil, dan kesimpulan. Archer \& $\mathrm{Ng}$ (2016, p.53) menyatakan aktivitas scientific method dalam kegiatan pembelajaran meliputi: menanya, membuat hipotesis, mengumpulkan dan mengolah data, diskusi dan penutup. Magner (2007, p.7) mendeskripsikan langkahlangkah scientific method untuk siswa yaitu: observasi awal, membuat hipotesis, membuat prediksi dan merancang percobaan, menguji hipotesis yang dibuat, dan menggambarkan kesimpulan. McCComas (2014, p.93) menyatakan langkah scientific method yang diajarkan untuk siswa memuat enam sampai sembilan langkah yang diawali dengan mengajukan pertayaan, dilanjutkan dengan mengumpulkan data, menganalisa hasil, dan diakhiri dengan mengkomunikasikan hasil.

D’Amico \& Gallaway (2010, p.37) menyatakan untuk mempermudah ingatan dan pemahahan langkah-langkah scientific method, yaitu meghafal dari singkatan SCIENTIFIC yaitu: (1) $\mathrm{S}=$ state the problem; (2) $\mathrm{CI}=$ collect Information; (3) $\mathrm{E}=$ experiment with data; (4) $\mathrm{N}=$ note and record the results: $(5) \mathrm{C}=$ contemplate solutions; (6) $\mathrm{E}=$ evaluate and state a conclusion. Permendikbud Nomor 103 Tahun 2014 tentang Pembelajaran pada Pendidikan Dasar dan Pendidikan Menengah menjelaskan pendekatan saintifik dapat didefinisikan sebagai pembelajaran yang dirancang sedemikian rupa sehingga siswa secara aktif memperoleh pengetahuan, keterampilan dan sikap melalui tahapantahapan mengamati, merumuskan pertanyaan, mengumpulkan data/informasi dengan berbagai teknik, mengolah/menganalisis data/informasi, dan menarik kesimpulan dan mengomunikasikan hasil.

Berdasarkan penjelasan tersebut, yang dimaksud pembelajaran dengan pedekatan saintifik adalah pembelajaran yang mengadopsi langkah-lagkah metode saintifik atau scientific method. Scientific method merupakan langkah atau tahap teratur dan sistematis yang digunakan dalam memecahkan suatu masalah ilmiah. Kegiatan pembelajaran dengan pedekatan saintifik meliputi kegiatan: (1) mengamati, (2) menanya, (3) mengumpulkan informasi, (4) mengasosiasi/ menalar, dan (5) mengkomunikasikan.

Pendekatan saintifik tersebut sesuai dengan standar pembelajaran matematika SMP. NCTM (2000, p.221) menjelaskan standar pembelajaran matematika SMP yaitu: (1) siswa harus terlibat aktif terkait dengan kemampuan menemukan dan menentukan struktur, (2) menduga dan memverifikasi, (3) berpikir tentang hipotesis, (4) memahami sebab akibat, (5) abstraksi dan menarik kesimpulan.

Salah satu materi matematika SMP yang cocok menggunakan pendekatan saintifik adalah materi statistika. Statistika adalah materi matematika yang penting dan berguna bagi siswa. Muschla, Muschla, \& Muschla (2012, p.65) menyatakan bahwa statistika adalah cabang ilmu matematika yang berfokus pada pengumpulan, pengorganisaian, dan pengolahan data. Metz (2010, pp.1-27) menyatakan bahwa pendidikan statistik menjadi komponen yang semakin penting dari pendidikan matematika. Hal senada disampaikan Barnet (Morris, 1989, p.50) bahwa ilmu statistika adalah kunci untuk memahami dunia. Moore (Garfield \& Ben-Zvi, 2008, p.4) menyatakan bahwa statistik adalah pengetahuan tentang pengumpulan data yang digunakan dalam setiap aspek kehidupan modern.

$\operatorname{NCTM}(2000$, p.249) menyebutkan siswa kelas menengah harus memiliki pengalaman mengumpulkan, pengorganisasian, dan penyajian data baik menyajikan data dalam bentuk tabel, plot garis, grafik batang, dan grafik garis. Selain itu siswa harus memahami langkah-langkah menentukan ukuran pemusatan data tunggal seperti median, modus, dan range. Lebih lanjut $\operatorname{NCTM}(2000$, p.249) menyebutkan bahwa siswa 
kelas 6-8 guru harus membangun pengalaman dasar siswa untuk membantu siswa menjawab pertanyaan seperti menyangkut hubungan antara populasi atau sampel dan pengamatan mereka.

Berdasarkan hasil pengamatan dan wawancara dengan guru di MGMP Kabupaten Tulang Bawang Barat Provinsi Lampung, statistika lebih fokus untuk menentukan ukuran pemusatan data dan membaca diagram. kegiatan pembelajaran materi statistika belum mengajarkan materi pengumpulan, teknik penyajian, dan analisis data.

Permendikbud Nomor 104 Tahun 2014 menjelaskan bahwa penilaian hasil belajar siswa mencakup tiga kompetensi yaitu: kompetensi sikap, kompetensi pengetahuan, dan kompetensi keterampilan. Penilaian dilakukan dengan menggunakan tes dan nontes dalam bentuk tertulis maupun lisan.

Anderson (Gable, 1986, p.3) mendeskripsikan sikap sebagai kualitas yang ditampilkan seseorang mengenai cara merasakan dan mengekspresikan emosinya. Permendikbud Nomor 104 Tahun 2014 tentang Pembelajaran pada Pendidikan Dasar dan Pendidikan Menengah menyebutkan bahwa ranah kompetensi sikap meliputi sikap spiritual dan sikap sosial. Miller, Linn, \& Gronlund (2009, p.314-315) menambahkan sikap sosial seperti peduli akan keselamatan yang lain, hormat pada peraturan, sensitif terhadap isu sosial dapat diukur dengan teknik observasi. Nitko \& Brookhart (2011, p.325) menyatakan penilaian diri sendiri dan teman sebaya sangat berguna untuk menilai sikap siswa.

Bloom (Nitko \& Brookhart, 2011, p.25) menyebutkan bahwa ranah pengetahuan meliputi: mengingat kembali sesuatu yang khusus dan umum, mengingat metode dan proses, mengingat pola, struktur atau aturan. Permendikbud Nomor 104 Tahun 2014 menyebutkan sasaran penilaian hasil belajar oleh pendidik pada dimensi pengetahuan terdiri atas: faktual, konseptual, prosedural, dan metakognisi. Menurut Miller, Linn, \& Gronlund ( 2009, p.202) menyatakan bahwa tes pilihan ganda adalah salah satu bentuk tes yang secara luas dapat diguna untuk mengukur berbagai pengetahuan.

Permendikbud Nomor 58 Tahun 2014 tentang Pembelajaran pada Pendidikan Dasar dan Pendidikan Menengah menyebutkan bahwa ranah sasaran penilaian hasil belajar kompetensi keterampilan terdiri atas keterampilan abstrak dan keterampilan konkret. Sasaran penilaian hasil belajar keterampilan abstrak berupa kemampuan belajar terkait: mengamati, menanya, mengumpulkan informasi, menalar, dan menarik kesimpulan. Nitko \& Brookhart (2011, p.246) menyatakan tes kinerja mengukur hasil belajar siwa yang membutuhkan untuk mengkreasikan hasil, mendemonstrasikan proses atau keduanya.

Pendekatan saintifik yang dikenalkan oleh Kurikulum 2013 memunculkan masalah baru. Masalah tersebut terkait dengan penyusunan perangkat pembelajaran dengan pendekatan saintifik. Guru matematika SMP Daerah Istimewa Yogyakarta mengalami hambatan dalam menyusun RPP dengan pendekaan saintifik. Fakta ini diperoleh dari hasil penelitian yang dilakukan oleh Rusindrayanti \& Santoso (2015, p.70) menye-butkan langkah-langkah kegiatan pembelajaran dalam RPP yang disusun oleh guru SMP Daerah Istimewa Yogyakarta belum lengkap memuat langkah pendekatan saintifik secara sempurna. Berdasarkan hasil observasi di lapangan, banyak guru belum memahami pendekatan saintifik dengan baik. RPP dan LKS yang dibuat oleh guru sebagian besar mengadopsi perangkat dari internet tanpa melakukan penyesuaian dengan keadaan dan kebutuhan siswa. Hilman \& Retnawati (2015, p.49) menyatakan pembelajaran matematika akan berjalan secara efektif apabila perangkat pembelajaran dipersiapkan dan dikembangkan sendiri oleh guru. Akibatnya, pelaksanaan pembelajaran belum berjalan dengan maksimal. Keterampilan guru mengembangkan RPP dan LKS masih perlu ditingkatkan.

Sebelumnya telah dilakukan penelitian pengembangan perangkat pembelajaran matematika SMP dengan menggunakan pendekatan saintifik (Maprokhi 2015, p.163; Prasetyo \& Santoso, 2015, p.1), akan tetapi perangkat pembelajaran yang dikembangkan tidak spesifik mengembangkan perangkat pembelajaran materi statistika. Perangkat pembelajaran yang dikembangkan tidak memuat materi statistika kelas VIII dan kelas IX.

Melihat penjelasan tersebut, peneliti memandang perlu mengembangkan perangkat pembelajaran matematika materi statistika dengan pendekatan saintifik. Dengan demikian tujuan dari penelitian ini adalah untuk menghasilkan perangkat pembelajaran matematika materi statistika dengan pendekatan saintifik yang berkualitas. Kualitas perangkat pembelajaran yang dimaksud harus memenuhi kriteria valid, praktis, dan efektif. 


\section{METODE}

Perangkat pembelajaran statistika SMP dengan pendekatan saintifik yang layak diperoleh dengan melakukan penelitian pengembangan. Penelitian ini mengadopsi model penelitian dan pengembangan dari Borg \& Gall (1983, p.775) yang bertujuan untuk menghasilkan perangkat pembelajaran matemtatika SMP materi statistika dengan pendekatan saintifik yang layak digunakan dalam kegiatan pembelajaran. Prosedur pengembangan pada penelitian ini mengadaptasi model pengembangan dari model pengembangan Borg \& Gall yang terdiri atas 10 langkah yaitu: (1) studi pendahuluan, (2) perencanaan, (3) mengembangkan produk awal, (4) uji coba awal, (5) revisi produk awal, (6) uji coba terbatas, (7) revisi produk operasional, (8) uji coba lapangan, (9) revisi produk akhir, (10) desiminasi.

Data penelitian diperoleh dengan melakukan uji coba produk yang dikembangkan. Uji coba produk dilaksanakan di SMP Negeri 1 Tulang Bawang Udik, Lampung. Uji coba produk terdiri atas dua tahap, yaitu uji coba terbatas dan uji coba lapangan. Uji coba terbatas dan uji coba lapangan dilaksanakan dari tanggal 04 Febuarai - 08 Maret 2016. Kegiatan pembelajaran dilaksanakan untuk delapan kali pertemuan. Enam pertemuan untuk kegiatan pembelajaran, satu kali pertemuan untuk tes kompetensi pengetahuan, dan satu kali pertemuan untuk tes kompetensi keterampilan.

Sebagai sumber data uji coba lapangan, dilibatkan dua orang guru mitra dan enam orang siswa kelas IX SMP Negeri 1 Tulang bawang Udik yang mewakili kelompok kemampuan rendah, sedang, dan tinggi. Sebagai sumber data uji coba lapangan, dilibatkan tiga orang guru matematika dan 57 siswa kelas VIIA dan VIID SMP Negeri 1 Tulang Bawang Udik.

Secara sistematis prosedur pengembangan perangkat pembelajaran mengadopsi langkah model pengembangan Borg \& Gall. Prosedur pengembangan meliputi tiga tahapan yaitu: (1) tahap studi pendahuluan, (2) tahap desain produk, (3) tahap pengembangan dan evaluasi.

Tahap studi pendahuluan terdiri atas kegiatan studi lapangan dan studi pustaka. Kegiatan studi lapangan dilakukan untuk mengetahui pelaksanaan pembelajaran matematika serta ketersediaan perangkat pembelajaran dengan pendekatan saintifik di sekolah. Fakta yang ditemukan dilapangan akan dijadikan pertimbangan dalam menyusun perangkat pembelajar- an dengan pendekatan saintifik. Pada kegiatan studi pustaka, peneliti melakukan kajian terhadap konsep-konsep dan teori-teori yang berkenaan dengan pendekatan saintifik dan perangkat pembelajaran yang akan dikembangkan.

Kegiatan pada tahap desain produk meliputi penyusunan draf produk berupa RPP dan LKS matematika SMP materi statistika dengan pendekatan saintifik. Penyusunan produk dimulai dengan kegiatan menetapkan tujuan belajar, merancang skenario atau kegiatan belajar mengajar, merancang perangkat pembelajaran, merancang materi pembelajaran, dan alat evaluasi hasil belajar. Selain itu peneliti juga merancang instrumen kevalidan, kepraktisan, dan keefektifan sebagai alat untuk mengukur kualitas produk yang dikembangkan.

Tahap pengembangan dan evaluasi meliputi tiga kegiatan yaitu: validasi ahli, uji coba terbatas, dan uji coba lapangan. Validasi ahli dilakukan untuk memperoleh penilaian atau menguji validitas desain awal perangkat pembelajaran. Uji coba terbatas dan uji coba lapangan dilakukan untuk mengetahui keefektifan dan kepraktisan perangkat yang dikembangkan.

Data diperoleh dengan menggunakan lembar validasi, lembar observasi keterlaksanaan pembelajaran, lembar penilaian kepraktisan oleh siswa, lembar keterbacaan, lembar penilaian kepraktisan oleh guru, dan instrumen kefektifan perangkat pembelajaran. Instrumen keefektifan terdiri atas instrumen penilaian kompetensi sikap, kompetensi pengetahuan, dan kompetensi keterampilan.

Data kevalidan perangkat pembelajaran diperoleh dengan menggunakan lembar validasi RPP, lembar validasi LKS. Lembar validasi menggunakan skala Likert yang terdiri atas lima skala penilaian yaitu: (5) sangat baik, (4) baik, (3) cukup baik, (2) kurang baik, dan (1) tidak baik.

Data kepraktisan perangkat pembelajaran diperoleh dengan menggunakan lembar kepraktisan perangkat pembelajaran oleh guru, lembar penilaian kepraktisan perangkat pembelajaran oleh siswa, lembar keterbacaan oleh siswa, dan hasil observasi keterlaksanaan pembelajaran. Lembar kepraktisan perangkat pembelajaran oleh guru menggunakan skala likert yang terdiri atas lima skala penilaian yaitu: (5) sangat baik, (4) baik, (3) cukup baik, (2) kurang baik, dan (1) tidak baik. Lembar penilaian kepraktisan perangkat pembelajaran oleh siswa dan lembar keterbacaan oleh siswa menggunakan skala Likert yang terdiri atas lima skala penilaian 
yaitu: (5) sangat jelas, (4) jelas, (3) cukup jelas, (2) kurang jelas, dan (1) tidak jelas.

Data keefektifan perangkat pembelajaran diperoleh dengan menggunakan instrumen penilaian kompetensi sikap, instrumen penilaian kompetensi pengetahuan, dan instrumen penilaian kompetensi keterampilan. Instrumen penilaian sikap berupa lembar observasi penilaian sikap siswa, penilaian diri sendiri, dan penilaian teman sejawat. Instrumen penilaian kompetensi pengetahuan adalah tes tertulis dalam bentuk soal pilihan ganda. Instrumen penilaian kompetensi keterampilan adalah tes tertulis dalam bentuk tes kinerja.

Data hasil penelitian terdiri atas data kuantitatif dan data kualitatif. Data kualitatif diperoleh dari komentar, saran, revisi dari ahli maupun guru. Data kualitataif dianalisis secara deskriptif kualitatif dan disimpulkan sebagai masukan untuk merevisi produk yang dikembangkan. Data kuantitatif diperoleh dari validitas oleh ahli, kepraktisan oleh guru, kepraktisan oleh siswa, keterlaksanaan pembelajaran, dan keterbacaan oleh siswa. Data kuantitatif diperoleh dari hasil penilaian kompetensi pengetahuan dan keterampilan, sedangkan data kualitatif diperoleh dari hasil pengisian lembar validasi, angket penilaian guru, angket penilaian siswa dan lembar observasi keterlaksanaan pembelajaran. Data kuantitatif yang diperoleh dikonversi menjadi data kualitatif. Acuan konversi skor menjadi skala 5 menurut Widoyoko (2011, p.238) disajikan pada Tabel 2.
Tabel 2. Acuan Konversi Skor Skala Lima

\begin{tabular}{cc}
\hline Interval & Kriteria \\
\hline$X>\bar{X}_{i}+1,8 S b_{i}$ & Sangat baik \\
$\bar{X}_{l}+0,6 S b i<X \leq \bar{X}_{l}+1,8 S b i$ & Baik \\
$\bar{X}_{l}-0,6 S b i<X \leq \bar{X}_{l}+0,6 S b i$ & Cukup \\
$\bar{X}_{l}-1,8 S b i<X \leq \bar{X}_{l}-0,6 S b i$ & Kurang \\
$X \leq \bar{X}_{l}-1,8 S b i$ & Sangat kurang \\
\hline
\end{tabular}

Keterangan: (Widoyoko, 2011, p.238)

$\bar{X}=$ total skor aktual

$X_{i}=\frac{1}{2} \times$ rata-rata skor ideal

$=($ skor maksimum + skor minimum $)$

Sbi $=\frac{1}{6} \times$ simpangan baku ideal

$=($ skor maksimum - skor minimum $)$

Instrumen penilaian kevalidan RPP, LKS oleh ahli diubah kedalam kriteria kualitatif. Perangkat pembelajaran berupa RPP dan LKS dikatakan valid apabila skor validasi minimal berada pada kriteria baik. Kriteria kevalidan produk yang dikembangkan ditunjukkan pada Tabel 3.

Data kepraktisan perangkat pembelajaran terdiri atas data hasil penilaian perangkat pembelajaran oleh guru, data hasil penilaian perangkat pembelajaran oleh siswa, data keterlaksanaan pembelajaran. Dari rata-rata yang didapatkan dari data hasil penilaian perangkat pembelajaran oleh guru, data hasil penilaian perangkat pembelajaran oleh siswa kemudian diubah kedalam kriteria kualitatif. Kriteria kepraktisan produk yang dikembangkan ditunjukkan pada Tabel 4 dan Tabel 5.

Tabel 3. Kriteria Validasi Perangkat Pembelajaran

\begin{tabular}{|c|c|c|c|c|c|c|}
\hline \multirow{2}{*}{ Kriteria } & \multicolumn{6}{|c|}{ Interval } \\
\hline & \multicolumn{3}{|c|}{ RPP } & \multicolumn{3}{|c|}{ LKS } \\
\hline Sangat valid & & $x>$ & 163,8 & & $x>$ & 88,2 \\
\hline Valid & 158,6 & $<x \leq$ & 163,8 & 85,4 & $<x \leq$ & 88,2 \\
\hline Cukup valid & 101,4 & $<\mathrm{x} \leq$ & 158,6 & 54,6 & $<\mathrm{x} \leq$ & 85,4 \\
\hline Kurang valid & 70,2 & $<\mathrm{x} \leq$ & 101,4 & 37,8 & $<\mathrm{x} \leq$ & 54,6 \\
\hline Tidak valid & & $\mathrm{x}<$ & 70,2 & & $\mathrm{x}<$ & 37,8 \\
\hline
\end{tabular}

Tabel 4. Kriteria Kepraktisan Perangkat Pembelajaran oleh Guru

\begin{tabular}{|c|c|c|c|c|c|c|}
\hline Kategori & & RPP & & & LKS & \\
\hline Sangat Praktis & & $X>$ & 88,2 & & $X>$ & 54,60 \\
\hline Praktis & 85,4 & $<\mathrm{X} \leq$ & 88,2 & 52,87 & $<\mathrm{X} \leq$ & 54,60 \\
\hline Cukup Praktis & 54,6 & $<X \leq$ & 85,4 & 33,80 & $<X \leq$ & 52,87 \\
\hline Kurang Praktis & 37,8 & $<x \leq$ & 54,6 & 23,40 & $<x \leq$ & 33,80 \\
\hline Tidak Praktis & & $x<$ & 37,8 & & $x<$ & 23.4 \\
\hline
\end{tabular}


Jurnal Riset Pendidikan Matematika, 3 (2), November 2016 - 179

Choirul Mahmudah

Tabel 5. Kriteria Kepraktisan oleh Siswa

\begin{tabular}{lrrllcc}
\hline \multicolumn{1}{c}{ Kategori } & \multicolumn{3}{c}{ LKS } & & \multicolumn{2}{c}{ Keterbacaan } \\
\hline Sangat Praktis & & $\mathrm{X}>$ & 38 & & $\mathrm{X}>$ & 42 \\
Praktis & 36,8 & $<\mathrm{X} \leq$ & 38 & 41 & $<\mathrm{X} \leq$ & 42 \\
Cukup Praktis & 24 & $<\mathrm{X} \leq$ & 36,8 & 26 & $<\mathrm{X} \leq$ & 40,67 \\
Kurang Praktis & 17 & $<\mathrm{X} \leq$ & 24 & 18 & $<\mathrm{X} \leq$ & 26 \\
Tidak Praktis & & $\mathrm{X}<$ & 17 & & $\mathrm{X}<$ & 18 \\
\hline
\end{tabular}

Perangkat pembelajaran matematika SMP materi statistika dengan pendekatan saintifik dikatakan praktis apabila memenuhi kriteria: (1) Penilaian kepraktisan guru berada pada kategori minimal praktis, (2) penilaaian kepraktisan siswa berada pada kategori minimal praktis, (3) Panduan keterbacaan siswa berada pada kategori minimal praktis, dan (4) keterlaksanaan pembelajaran minimal mencapai $80 \%$

Hasil dari penilaian instrumen kompetensi sikap, instrumen kompetensi pengetahuan, dan instrumen keterampilan dianilis untuk menentukan keefektifan perangkat pembelajaran yang dihasilkan. Produk perangkat pembelajaran matematika dengan pendekatan saintifik dikatakan efektif apabila memenuhi kriteria berikut: (1) jumlah siswa yang mencapai ketuntasan kompetensi sikap secara klasikal mencapai > 75\% dengan kriteria ketuntasan B, (2) jumlah siswa yang mencapai ketuntasan kompetensi pengetahuan secara klasikal mencapai > 75\% dengan kriteria ketuntasan minimal B-, (3) jumlah siswa yang mencapai ketuntasan kompetensi keterampilan secara klasikal mencapai > 75\% dengan kriteria ketuntasan minimal B-.

\section{HASIL DAN PEMBAHASAN}

Sebelum mengembangkan bahan ajar, terlebih dahulu dilakukan tahap studi pendahuluan. Pada tahap ini seluruh kebutuhan untuk penelitian dikumpulkan, dikaji, serta dievaluasi untuk menentukan tujuan dan permasalahan sebagai patokan dalam penyusunan bahan ajar. Tahap studi pendahuluan terdiri atas kegiatan studi lapangan dan studi pustaka.

Kegiatan studi lapangan dilakukan dengan mengamati kegiatan guru dan siswa pada saat melaksanakan pembelajaran. Kegiatan studi lapangan dilakukan untuk mengetahui pelaksanaan pembelajaran matematika serta ketersediaan perangkat pembelajaran dengan pendekatan saintifik di sekolah. Berdasarkan hasil pengamatan dan wawancara diperoleh hasil: (1) proses pembelajaran sebagian besar masih didominasi oleh guru; (2) sebagian besar guru masih belum paham dalam menyusun RPP dengan pendekatan saintifik; (3) langkah-langkah pem- belajaran yang ada di RPP belum sesuai dengan langkah-langkah pendekatan saintifik; (4) guru masih kesulitan membuat instrumen penilaian sikap, tes kompetensi pengetahuan, dan tes kompetensi keterampilan.

Kegiatan studi pustaka dilakukan dengan mengumpulkan literatur dari berbagai sumber mengenai teori pendekatan saintifik. Peneliti juga mengumpulkan informasi dan sumber pustaka teori tentang RPP dan LKS sebagai landasan pengembangan perangkat yang akan dikembangkan. Selain itu peneliti juga mengumpulkan informasi terkait penyusunan instrumen penilaian sikap, kompotensi pengetahuan, dan kompetensi keterampilan sebagai salah satu aspek dari RPP dan instrumen keefektifan perangkat pembelajaran.

Hasil penelitian pendahuluan digunakan sebagai acuan untuk menyusun perangkat pembelajaran. Produk yang dihasilkan dalam penelitian ini berupa Rencana Pelaksanaan Pembelajaran (RPP) dan Lembar Kegiatan Siswa (LKS). RPP dan LKS dibuat mencakup semua materi statistika SMP. Selain RPP dan LKS, pada tahap ini juga disusun instrumen untuk mengukur keefektifan perangkat pembelajaran. Instrumen keefektifan terdiri atas instrumen kompetensi sikap, kompetensi pengetahuan, dan komptensi keterampilan. Selanjutnya produk yang dihasilkan pada tahap ini disebut draf 1 .

Draf 1 yang dihasilkan dibawa ke pakar untuk menentukan kevalidan perangkat pembelajaran yang dikembangkan. Rata-rata skor hasil penilaian ahli terhadap perangkat pembelajaran digunakan untuk menentukan kevalidan produk. Selain skor penilaian poduk, validasi menghasilkan data kualitatif berupa saran perbaikan perangkat yang dikembangkan. Berdasarkan masukan dari kedua validator, dilakukan perbaikan terhadap produk yang dikembangkan. Produk yang telah direvisi berdasarkan saran ahli disebut sebagai draf 2 .

Langkah selanjutnya setelah validasi adalah uji coba terbatas. Uji coba terbatas dilaksanakan tanggal 4 Februari 2016. Tahap uji coba terbatas melibatkan dua guru matematika dan 6 siswa kelas XI SMP N 1 Tulang Bawang Udik, 
Kabupaten Tulang Bawang Barat, Provinsi Lampung. Draf 2 yang telah diperbaiki berdasarkan saran validator diberikan kepada guru diberikan pada dua orang guru matematika untuk memperoleh saran perbaikan terhadap RPP dan LKS yang dikembangkan. Perangkat pebelajaran yang telah direvisi berdasarkan saran guru disebut sebagai draf 3. LKS hasil draf 2 juga diberikan kepada enam siswa kelas IX untuk mengetahui keterbacaan LKS yang dibuat.

Langkah selanjutnya adalah uji coba lapangan. Uji coba lapangan dilakukan untuk mengetahui kepraktisan dan keefektifan perangkat pembelajaran yang dikembangkan. Uji coba lapangan dilaksanakan di SMP Negeri 1 Tulang Bawang Udik, Kabupaten Tulang Bawang Barat, Provinsi Lampung. Uji coba lapangan melibatkan 57 siswa, dua orang guru penyaji dan satu orang guru sebagai observer keterlaksanaan pembelajaran. Uji coba lapangan dilakukan pada dua kelas dengan guru yang berbeda.

Perangkat pembelajaran yang telah direvisi berdasarkan hasil uji coba terbatas (draf 3) digunakan dalam kegiatan pembelajaran. Materi pelajaran pada uji coba lapangan ini adalah statistika kelas VII semester genap. Uji coba lapangan dilaksanakan dari tanggal 04 Februari - 08 Maret 2016. Kegiatan pembelajaran dilaksanakan untuk delapan kali pertemuan. Enam pertemuan untuk kegiatan pembelajaran, satu kali pertemuan untuk tes kompetensi pengetahuan, dan satu kali pertemuan untuk tes kompetensi keterampilan.

Uji coba lapangan menghasilkan sejumlah data yaitu: lembar penilaian perangkat pembelajaran oleh guru, lembar penilaian perangkat pembelajaran oleh siswa, dan lembar observasi keterlaksanaan pembelajaran, dan instrumen keefektifan perangkat pembelajaran. Kepraktisan perangkat pembelajaran dapat diketahui dari lembar penilaian guru dan siswa, lembar keterbacaan oleh siswa, dan lembar observasi keterlaksanaan pembelajaran. Sedangkan keefektifan dapat dilihat dari hasil penilaian kompetensi sikap, kompetensi pengetahuan, dan kompetensi keterampilan siswa.

Validasi ahli dilakukan untuk menilai keva-lidan produk yang dihasilkan. Hasil skor rata-rata validasi RPP adalah 171. Berdasarkan kriteris validasi ahli pada Tabel 3, skor rata-rata validasi RPP berada pada kriteria sangat valid. Hasil skor rata-rata validasi LKS adalah 89. Berdasarkan kriteris validasi ahli pada Tabel 3, skor rata-rata validasi LKS berada pada kriteria sangat valid. Berdasarkan kriteria minimal yang telah ditetapkan, dapat disimpulkan bahwa RPP dan LKS yang dikembangkan telah memenuhi kategori valid.

Kevalidan perangkat pembelajaran ini tercapai karena penyusunan perangkat pembelajaran dengan pendekatan saintifik sesuai dengan referensi. Penyusunan perangkat pembelajaran juga mengacu pada prinsip-pengembangan perangkat pembelajaran. Selain itu pemilihan materi disesuaikan dengan kompetensi dasar dan tingkat perkembangan pemahan dan kondisi lingkungan siswa.

Data kepraktisan diperoleh dari uji coba terbatas dan uji coba lapangan. Data kepraktisan diperoleh dari lembar penilaian kepraktisan perangkat pembelajaran oleh guru, lembar penilaian kepraktisan perangkat pembelajaran oleh siswa, lembar keterbacaan oleh siswa, dan lembar observasi keterlaksanaan pembelajaran.

Hasil skor rata-rata penilaian keprak-tisan RPP oleh guru adalah 87,33. Berdasarkan Tabel 4, penilaian RPP oleh guru mencapai kriteria sangat praktis. Hasil skor rata-rata kepraktisan LKS oleh guru adalah 57. Berdasarkan Tabel 4, penilaian LKS oleh guru mencapai kriteria sangat praktis.

Hasil rata-rata penilaian keterbacaan LKS oleh siswa kelas IX adalah 44. Berdasarkan Tabel 5 tentang kriteria penilaian perangkat pembelajaran oleh siswa, penilaian keterbacaan LKS oleh siswa mencapai kriteria sangat praktis.

Hasil rata-rata lembar penilaian kepraktisan LKS oleh siswa kelas VIIA adalah 37,64. Hasil rata-rata lembar penilaian kepraktisan LKS oleh siswa kelas VIID adalah 37,81. Berdasarkan Tabel 5 tentang kriteria penilaian perangkat pembelajaran oleh siswa, penilaian kepraktisan LKS oleh siswa mencapai kriteria sangat praktis.

Tabel 1. Keterlaksanaan Pembelajaran

\begin{tabular}{lcc}
\hline \multicolumn{1}{c}{ Pertemuan } & VIIA & VIID \\
\hline Kesatu & $82 \%$ & $84 \%$ \\
Kedua & $97 \%$ & $97 \%$ \\
Ketiga & $100 \%$ & $100 \%$ \\
Keempat & $100 \%$ & $100 \%$ \\
Kelima & $95 \%$ & $95 \%$ \\
Keenam & $89 \%$ & $92 \%$ \\
Ketujuh & $100 \%$ & $100 \%$ \\
Kedelapan & $100 \%$ & $100 \%$ \\
\hline Rata-rata & $95 \%$ & $96 \%$ \\
\hline
\end{tabular}


Jurnal Riset Pendidikan Matematika, 3 (2), November 2016 - 181

Choirul Mahmudah

Tabel 2. Skor Hasil Belajar siswa

\begin{tabular}{ccccccc}
\hline \multirow{2}{*}{ Keterangan } & \multicolumn{3}{c}{ VIIA } & \multicolumn{2}{c}{ VIIB } \\
\cline { 2 - 7 } & Sikap & Pengetahuan & Keterampilan & Sikap & Pengetahuan & Keterampilan \\
\hline jumlah siswa tuntas KKM & 28 & 24 & 25 & 29 & 27 & 27 \\
persentase siswa tuntas KKM & $100 \%$ & $85 \%$ & $89 \%$ & $100 \%$ & $93 \%$ & $93 \%$ \\
\hline
\end{tabular}

Skor rata-rata keterlaksanaan pembelajaran kelas VIIA adalah 95\%. Skor rata-rata keterlaksanaan pembelajaran kelas VIID adalah 96\%. Berdasarkan hasil penilaian kepraktisan oleh guru, penilaian kepraktisan oleh siswa, penilaian keterbacaan oleh siswa, dan keterlaksanaan pebelajaran, kriteria minimal kepraktisan perangkat pembelajaran yang ditatapkan sebelumnya telah tercapai. sehingga diperoleh kesimpulan perangkat pembelajaran memenuhi kritera praktis.

Kepraktisan perangkat pembelajaran yang dikembangkan tercapai karena penyusunan perangkat pembelajaran disusun dengan mempertimbangkan: (1) teori pendekatan saintifik yang diperoleh dari kajian pustaka, (2) alokasi waktu yang tersedia, (3) pemilihan materi sesuai dengan sarana yang ada, (4) pemilihan materi sesuai dengan tingkat perkembangan siswa, dan (5) bahasa yang digunakan disesuaikan dengan perkembangan siswa.

Data keefektifan perangkat pembe-lajaran diperoleh dari uji coba terbatas dan uji coba lapangan. Keefektifan perangkat pembelajaran ditinjau dari penilaian kompetensi sikap, kompetensi pengetahuan, dan kompetensi keterampilan. Berikut adalah rincian data keefektifan yang diperoleh dari uji coba terbatas dan uji coba lapangan.

Keefektifan pembelajaran dengan menggunakan RPP dan LKS yang dikembangkan diukur dari hasil penilaian kompetensi sikap siswa, ketuntasan uji kompetensi pengetahuan, dan uji kompetensi keterampilan. Penilaian kompetensi sikap siswa menunjukkan bahwa persentase ketuntasan kompetensi sikap siswa menunjukkan $100 \%$ siswa telah mencapai kriteria yang ditentukan yaitu > 2,85 (B). Hasil dari analisis uji kompetensi pengetahuan menunjukkan bahwa 89\% siswa kelas VIIA dan 93\% siswa kelas VIID mencapai kriteria yang ditentukan yaitu > 2,67 (B-). Hasil analisis uji kompetensi keterampilan menunjukkan $89 \%$ siswa kelas VIIA dan 93\% siswa kelas VIID mencapai kriteria yang ditentukan yaitu > 2,67 (B-). Berdasarkan persentase kompetensi sikap, kompetensi pengetahuan, dan kompetensi keterampilan dapat disimpulkan bahwa perangkat pembelajaran memenuhi kriteria minimal ke- efektifan perangkat pembelajaran yang ditetapkan.

Kriteria Keefekifan perangkat pembelajaran yang dikembangkan tercapai karena pendekatan saintifik pendekatan pembelajaran ini sesuai dengan pembelajaran matematika SMP. NCTM (2000, p.20) menyatakan bahwa mempelajari matematika dengan pemahaman, membangun pengetahuan baru dari pengalaman, dan pengetahuan sebelumnya akan memudahkan pembelajaran matematika selanjutnya. Senada dengan pendapat tersebut Kenedy, Tipss, \& Johnson (2008, p.55) menyatakan bahwa pembelajaran matematika akan bermakna apabila berorientasi pada siswa, bukan pembelajaran yang berpusat pada guru. Ditambahkan dalam $\operatorname{NCTM}(2000$, p.221) bahwa pembelajaran matematika dikelas menengah, siswa harus terlibat aktif terkait dengan kemampuan menemukan dan menentukan struktur, menduga dan memverifikasi, berpikir tentang hipotesis, memahami sebab akibat, abstraksi dan menarik kesimpulan.

Pendekatan saintifik sesuai dengan materi statistika. NCTM (2000, p.249) menyebutkan siswa kelas menengah harus memiliki pengalaman mengumpulkan, pengorganisasian, dan penyajian data baik menyajikan data dalam bentuk tabel, plot garis, grafik batang, dan grafik garis. Pendekatan saintifik melibatkan siswa secara aktif mengumpulkan informasi, mengorganisasikan data, dan mengkomunikasikan hasil dalam bentuk grafik melalui kegiatan mengamati, menanya, mengumpulkan informasi, menalar, dan mengkomunikasikan.

Pendekatan saintifik juga relevan dengan teori belajar konstruktivis. Teori belajar konstruktivis memiliki karakteristik berpusat pada siswa, melibatkan siswa secara langsung untuk membangun pengetahuan, melibatkan proses ilmiah dalam pembelajaran, melibatkan proses kognitif yang merangsang perkembangan intelektual siswa dan dapat mengembangkan karakter siswa. Slavin (2006, p.243) menyatakan bahwa belajar menurut aliran konstruktivisme adalah siswa sendiri yang harus aktif menentukan dan mentransfer dan membangun pengetahuan yang akan dimilikinya, dalam proses itu, siswa mengecek dan menyesuaikan pengetahuan baru yang dipelajari dengan pengetahuan yang 
telah dimiliki. Bruner (Carin \& Sun, 1975, p. 95) menyatakan pokok pembelajaran penemuan adalah memberikan kesempatan kepada siswa untuk menemukan sendiri suatu konsep sehingga konsep tersebut akan bertahan lama dalam ingatan.

Pemilihan objek pengamatan yang sesuai dengan kondisi lingkungan sekitar memiliki peranan penting untuk membangun pengetahuan statistika siswa. Kenedy, Tipss, \& Johnson (2008, p.490) menyatakan seharusnya data yang dikumpulkan pada pembelajaran statistika berasal dari kehidupan nyata dan kegiatan siswa. Mahayukti \& Made (2015, p.175) menyatakan bahwa dalam pembelajaran statistika, pemilihan masalah nyata merupakan keharusan untuk memastikan siswa memahami tantangan yang lebih kompleks.

\section{SIMPULAN}

Berdasarkan hasil temuan dan pembahasan yang telah diuraikan, penelitian menghasilkan produk berupa perangkat pembelajaran matematika SMP materi statistika dengan pendekatan saintifik untuk meningkatkan kompetensi sikap, kompetensi pengetahuan, dan kompetensi keterampilan yang valid, praktis, dan efektif serta layak digunakan. Aspek kevalidan perangkat pembelajaran ditinjau dari penilaian para ahli dan memenuhi kategori valid dengan kriteria sangat baik. Aspek kepraktisan memenuhi kategori praktis dengan kriteria sangat baik ditinjau penilaian kepraktisan oleh guru, penilaian kepraktisan oleh peserta didik, penilaian keterbacaan oleh siswa, dan keterlaksanaan pembelajaran. Aspek keefektifan telah tercapai dari perolehan hasil instrumen penilaian siswa pada sekolah yang dijadikan subjek uji coba menunjukkan lebih dari $75 \%$ siswa telah mencapai nilai KKM untuk hasil penilaian kompetensi pengetahuan dan keterampilan serta lebih dari $75 \%$ siswa mencapai nilai KKM penilaian kompetensi sikap.

\section{DAFTAR PUSTAKA}

Al-Atabi, M \& Namasivayam, S. (2013). Introducing research skills through the use of the scientific method in engineering labs. Journal of Engineering Science and Technology. 4(1), 56-61.

Archer, L. A. C \& Ng, K. E. (2016). Using the scientific method to engage mathematical modeling: an investigation of pi. Journal of Education in Science, 2(1), 51-56.
Borg, W. R., Gall, M. D., \& Gall, J. P.(2007). Educational research: an introduction. Boston, MA: Pearson Allyn and Bacon.

Carey, S. S. (2011). A beginers guide to scientific method. Boston, MA: Wadswort Cengage Learning.

Carin, A. A., \& Sund, R. B. (1989). Teaching science through discovery. London, UK: Merril Publishing Company.

D'Amico, J., \& Gallaway, K. (2010). Differentiated instruction for the midlle school science teacher. San Francisco, CA: Jossey-Bass

Gable, R. K. (1986). Instrument development in the affective domain. Boston, MA: Springer.

Garfield, J. B \& Ben-Zvi, D. (2008). Developing students' statistical reasoning. Minneapolis, MA: Springer

Glazunov, N. M. (2012). Foundation of scientific method. National Aviation University. Diunduh dari https://arxiv. org/abs/1212.1651

Gould, J. E. (2002). Concise handbook of experimental methods for the behavioral for and biological science. Boca Raton, FL: CRC Press LLC.

Haylock, D., \& Thangata, F. (2007). Key concepts in teaching primary mathematics. London, UK: SAGE Publictions Ltd.

Hilman, H., \& Retnawati, H. (2015). Pengembangan perangkat pembelajaran matematika SMP dengan metode inkuiri pada persamaan dan pertidaksamaan linear satu variabel. Jurnal Riset Pendidikan Matematika, 2(1), 40 - 50. doi:http://dx.doi.org/10.21831/jrpm.v2i1 . 7149

Kennedy, L. M., Tipps, S., \& Johnson, A. (2008). Guiding children's learning of mathematics. Belmont, CA: Thomson Higher Education.

Kneidel, S. (1998). Creepy crawlies and the scientific method: more than 100 handson science experiments for children. Tampa, FL Fulcrum Publisher. 
Magner, L. (2007). The scientific method in fairy tale forest. Saline County, AR: Pieces of Learning.

Maprokhi, M. (2015). Pengembangan perangkat pembelajaran matematika SMP kelas VIII semester genap dengan pendekatan saintifik. PYTHAGORAS: Jurnal Pendidikan Matematika, 10(2), 168-178. doi:http://dx.doi.org/10.21831/pg.v10i2.9 152

McCComas, W. F. (2014). The language of science education. Rotterdam: Sense Publisher

Mendikbud. (2013). Peraturan Menteri Pendidikan dan Kebudayaan Nomor 64 Tahun 2013 tentang Standar Isi Pendidikan Dasar dan Menengah

Mendikbud. (2014a). Peraturan Menteri Pendidikan dan Kebudayaan Nomor 58 Tahun 2014 tentang Kurikulum 2013 SMP/MTs Bagian Pedoman Mata Pelajaran (PMP) Matematika.

Mendikbud. (2014b). Peraturan Menteri Pendidikan dan Kebudayaan Nomor 103 Tahun 2014 tentang Pembelajaran Pada Pendidikan Dasar dan Pendidikan Menengah.

Mendikbud. (2014c). Peraturan Menteri Pendidikan dan Kebudayaan Nomor 104 Tahun 2014 tentang Penilaian Pada Pendidikan Dasar dan Pendidikan Menengah.

Metz, M. L. (2010). Using GAISE and NCTM standards as frameworks for teaching probability and statistics to pre-service elementary and middle school mathematics teachers. Journal of Statitics education, 18(3), 1-27.

Miller, D. M., Linn, R. L., \& Gronlund, N. E. (2009). Measurement and assessment in teaching. Upper Saddle River, NJ: Pearson.

Morris, R. (1989). Studies mathematics education. Mayenne: Unesco.

Muschla, J .A., Muschla, G.R., \& Muschla, E. (2012). Teaching he common core math standards with hands-on activities, grades 6-8. San Francisco, CA: Jossey-Bass.
National Council of Teachers of Mathematics. (2000). Principles and standards for school mathematics. Reston, VA: National Council of Teachers of Mathematics.

Nitko, A. J., \& Brookhart, S. M.(2011). Educational assesment of student. Upper Saddle River, NJ: Pearson Publisher.

Prasetyo, B., \& Santosa, R. (2015). Pengembangan perangkat pembelajaran matematika untuk SMP kelas VII semester genap dengan pendekatan saintifik. PYTHAGORAS: Jurnal Pendidikan Matematika, 10(2), 117-128. doi:http://dx.doi.org/10.21831/pg.v10i2.9 122

Republik Indonesia .(2003). Undang-Undang RI Nomor 20 Tahun 2003, tentang Sistem Pendidikan Nasional

Rothchild, I. (2006). Induction, deduction, and scientific method an eclectic overview of the practice of science. Cleveland, $\mathrm{OH}$ : Society for the Study of Reproduction.

Rudolp, J. L. (2005). Epistimology for the MASSES: The origins of "the scientific method" in American School. History of Education Quarterly, 45(3),341-376.

Rusindrayanti, R., \& Santoso, R. (2015). Implementasi pendekatan saintifik mapel matematika kelas VII tahun pelajaran 2013/2014 pada kurikulum 2013 DIY. PYTHAGORAS: Jurnal Pendidikan Matematika, $\quad$ 10(1), 80-94. doi:http://dx.doi.org/10.21831/pg.v10i1.9 112

Mahayukti, G.A \& Made, I. M. (2015). Development of online-problem based learning model in statistical method course. International Conference on Research, Implementation and Education of Mathematics And Sciences, 2, 169-176. Retrieved from http://eprints.uny.ac.id/ 23022/1/ME\%20-\%2024.

Slavin, R.E. (2006). Educational psychology theory and practice. Boston, MA: Pearson Education. 